\title{
Towards Vision 20-2020: The Role of Language and Literature in National Development
}

\author{
Anthony A. Olaoye \\ Department of Linguistics and African Languages, University of Abuja, Nigeria
}

\begin{abstract}
This is a sociolinguistic paper which discuses the strategies for the actualization of the Federal Government of Nigeria's vision 20:2020. The role of language and literature is seen here as a catalyst for national development. The vision is that Nigeria should become one of the top 20 global economies by the year 2020, through the implementation of her 7-point-agenda crafted from the United Nation's Millennium Development Goals. Education for All (EFA) is one of the goals that Nigeria desires to achieve by the year 2020, and education is believed to be capable of eradicating poverty and diseases. Education is also believed to be a tool for the promotion of peace, integration and unity. The author therefore posits that language education can be used as a roadmap to national development and democratic greatness. The paper discusses the correlation between language and youth empowerment, socio-political and economic order, technological advancement, democracy and national rebranding. The author then recommends, among other things, that the Federal Government of Nigeria should invest more on multilingual, multicultural and mother tongue education, if her vision is to become a reality and not a dream.
\end{abstract}

Index Terms - vision 20-2020, millennium, roadmap, rebranding, empowerment, democracy, mother-tongue, andragogy, metalanguage

\section{INTRODUCTION}

Language is the vehicle through which people's culture is transmitted. It is an index of identity which serves as a repository of a people's culture, industry and exploits. It is language that differentiates the homo-sapiens from other animals. The most effective engine of a people's culture is their mother tongue (MT). Indigenous languages are treasures of culture and self-identity. In other words, language is the indicator of history and self- identification (Solanke, 2006). It is an indispensable cultural legacy with which all forms of human interactions are carried out. According to Nwadike (2004) it is the key to the heart of the people. If we lose the key, we lose the people. If we treasure the key and keep it safe, it will unlock the door to wealth or affluence, thus bringing about national development.

This development ranges from growth in education (i.e. intellectual growth), politics, economy, science and technology. In educational process, language is the main pillar through which man has to plan, instruct and evaluate programmes. The development of individuals in respect of their aspiration in the society means development of a nation. Individuals develop educationally, socially, economically, politically and culturally through their interaction with government agencies that disseminate ideas and policies through various media in the languages that the individual's best understand. According to Aziza (1998) national development is a gradual and advanced improvement through progressive changes in the sociopolitical life of the nation. National development refers to the growth of the nation in terms of internal cohesion, integration, unity, economic well-being, mass participation in government, and educational growth, all of which are pathfinders to vision 20-2020.

Language is a catalyst in educational development which is an important index of national development. Qualitative education in any nation is not a luxury, but an imperative to national development. In order to achieve national cohesion and unity, Nigeria recognizes the importance of mother tongue education hence she states in her National Policy on Education (NPE) that the language of instruction in the primary schools should be initially in the child's mother tongue or the language of the immediate community. Indigenous language is the most important tool with which society is organized, and it is hardly possible to talk of national development without including the language with which the people formulate their thoughts and ideas.

Multilingual education is capable of eradicating illiteracy. It provides political awareness and sociopolitical stability. Government's programmes and policies reach the grassroots with the use of indigenous languages. National unity depends largely on mutual understanding of each other's language and culture. This is why Nigeria considers it to be in the interest of national unity that each child should be encouraged to learn one of the three major Nigerian languages other than his own MT. Unity means strength or power, and it is language that empowers and unifies people. Languages therefore confer power on a nation.

\section{A. Language and Youth Empowerment}

Language is the most fundamental and important tool for youth empowerment. It is a weapon for the uplift of the underprivileged, the marginalized, the un-informed or the illiterates in the society. The culture of reforms initiated by 
the previous administration is designed to engender sustainable change in democratic governance. This reform is to be carried out through education, and language is the tool for doing this. This is one of the Millennium Development Goals (MDGs) that runs through the National Economic Empowerment and Development Strategy (NEEDS). Youth empowerment is a re-branding enterprise, as the empowered youths are likely to shun corruption, and make positive contribution to national economic growth, peace, security and political stability.

Empowerment is the process whereby people are enabled or given the opportunity to improve in order to contribute to positive change. It takes varied forms and dimensions which include activities like individual self-assertion, selfimprovement, collective bargaining or resistance in order to challenge existing power relations (Okeshola, 1995). Self empowerment takes varied forms such as education, apprenticeship, usurpation, domination and force. Education is the most fundamental and important tool for empowerment or for the achievement of social justice and equity. Social scientists prescribe education as a tool for the up-lift of the underprivileged, the marginalized, and the oppressed within the society (Graham-Brown, 1991). Education is therefore a veritable instrument for promoting empowerment, and best done through the medium of languages.

Modern man can hardly contemplate communal life without the instrument of language. Performance, especially spoken language, defines personality. For the teacher, his credibility is almost entirely anchored on his competence in communicating ideas, and stimulating learning through the use of language. Articulate and well-spoken teachers always invariably win the hearts and respect of their students.

Feminists have advanced the issue of empowerment of women through education as a means of challenging patriarchal ideology of male domination and women subordination. Empowerment entails life-long struggle for survival and transforming the structures and institutions (e.g. laws, social practice, political process, religious matters) that seem to perpetuate or reinforce gender discrimination and social inequality. According to Graham-Brown (1991), for the individual, empowerment through education promises an escape from poverty, oppression. It also promises greater social prestige, job mobility and better future prospect. Education empowers through language.

Language and language studies empower those who are engaged in them. Language as a means of communication is the corner stone of any educational process (Ige, 2000). It plays a vital role in education as a subject and it is also a medium of instruction. Education, whether formal or informal, is carried out through the medium of some languages, and learning at any level is largely verbal (Awoniyi, 1978). Language, whether spoken or written, is the vehicle through which knowledge is imparted, and knowledge is power. One of the cardinal points in the Federal Government's National Economic Empowerment and Development Strategy (NEEDS) is education, and language education is a key tool and bridge to the future (Olaoye, 2004). It empowers children and the youth to take charge of their lives. This involves acquisition of skills and knowledge that would prepare them for the world of work.

\section{B. Language, Literature and National Development}

A tripartite relationship between or among languages, literature and culture (whether foreign or indigenous) has been well established and documented (Olaoye, 2002, Isyaku, 2004). According to them, there is no literature without language. Culture and language too are inseparable and the trios are intricately interwoven. They play vital role in man's education and national development. Literature is an art which entertains and instructs. It warns people of danger, and instructs by opening people's eyes to a wide range of experiences and a deeper understanding of these experiences. According to Fatokun (1992) Literature presents situations, interactions and oppositions. It suggests a wide range of values and attitudes. To understand an ethnic group and their culture one may have to turn to their oral and written narratives, their drama and poetry. A good piece of literature can be regarded as an authentic mirror image of its society and time. Through satire, proverbs and symbolism, literary artists communicate ideas, thoughts and feelings about social ills in the society which they criticize with prussic diction. Proverbs, for instance, are a lesson in prudence, generosity, patience and wisdom all of which are indispensable to the guidance of mankind and the stability of the society. Literary artists use languages to ridicule or condemn anti-social behaviours such as corruption, assassination, political thuggery, religious intolerance, oppressive rule or dictatorship, any form of human degradation and undemocratic practices.

Through historical literature, our knowledge of the society is widened. According to Asade (2000) we learn from historical literature about seemingly immortal despots and their ignoble and sorrowful end, and that their mysterious death was engendered by the avalanche of atrocities and carnage they had masterminded and executed. This knowledge helps people in charting new and humanistic, sociopolitical and economic course, which leads to a new world order. This is the contribution of literature to national development.

Culture is defined as the particular systems of art, thought and custom of a society. It is the whole way of life of a people, the social heritage that the individual acquires as a member of his group. It is the entire attitude, perception and specific traits of civilization that confer to a people and its place in the universe. These traits are speech norms, etiquette, ideologies, ethics, stereotypes, artifacts, technologies, intellectual production, etc. Language whether foreign or indigenous, is thus an indelible mark of a people's identity. According to Fani-kayode (2006) the core values of our people must be the pivot for national reforms. He enjoins that our traditional values should be embedded in honesty, transparency, respect for institutions, constituted authorities and the sanctity of human person and life. These core values are reflected in the people's identity, cultures, traditions and systems, most times encapsulated in their languages. A child that grows up guided by the positive values of the society will possess a healthy and progressive mind in 
adulthood (Opega, 2004). Therefore, the teaching and learning of languages, literature and culture will afford the learner an understanding of the problems of the society. We cannot, therefore, overemphasize the importance of languages, literature and culture as three interrelated sociolinguistic variables from whose milk human beings must drink in order to develop a healthy soul in a healthy body.

\section{Languages, Civic Responsibility \& Democracy}

The constitution of the Federal Republic of Nigeria provides that citizens have among others the following: allegiance to the constitution, respect for its ideals and institutions as well as the National Flag, National Anthem, National Pledge, and respect for properly constituted authorities. Other duties include protecting and preserving public property, shunning violence, eschewing corruption and squandermania, and contributing to the good name and defense of the country. Citizens have the right to vote and be voted for. They have freedom of movement, speech, association, and the right to human dignity, personal liberty and fair hearing.

Language is an indispensable cultural legacy with which all forms of human interactions are carried out. It is capable of destroying or mending relationships. The creation of a new democratic culture depends on indigenous language for the articulation of democratic ideals. A given political thought is usually expressed by means of language. It determines the stability and success or otherwise of a given democratic experience. Political contests depend on the use of language, as in violent or abusive language.

Songs are composed in abusive diction to denigrate people and their ideals. Campaign language is a social mask for hiding party's selfish motives. The umbrella as an emblem is a sign language. These symbols communicate deep meaning. The umbrella symbolically represents the provision of a shade or a shelter for protection against adverse weather conditions, poverty and material deprivation (Bako, 2004). Political speeches, slogans and emblems are expected to be goal-directed. These goals are best achieved with the use of indigenous languages. If and when the business of the National Assembly is conducted in indigenous languages, national development will be accelerated.

\section{INDIGENOUS LANGUAGES AND TECHNOLOGICAL DEVELOPMENT}

Language is a vehicle of thought and the expression of culture. It expresses a people's way of life, their perception of things and their world view. This embodies their ideals and innovations, which embrace respect for technological and scientific innovations (Ishima, 2004). Science and Technology can be acquired and better understood through the indigenous languages. For indigenous languages to be used for the teaching and learning of science and technology, these MTs need to be developed in terms of their orthographies, spelling and vocabulary reform, including syntactical simplification, and translation through the use of lexicographic strategies and the linguistic indigenization policy of borrowing, coinage, semantic extension, etc. Through these linguistic re-engineering processes our indigenous languages will become a veritable vector of technological advancement, and a catalyst for the achievement of vision 20 2020.

\section{A. Metalanguage}

Metalanguage is defined in Encyclopedia Britannica (1981:5) as the study of a branch of linguistics that deals with the relation of language to other areas of a person's culturally determined behavior, e.g. the study of gestures, facial expression, voice quality, mannerism and other aspects of speech events. Metalanguage is the language used to discuss or describe other languages. Language used in describing some technical terms and vocabulary of English is called metalanguage. Metalanguage according to Olalekan (2001) is designed to take care of medical and scientific terms in English and other international. For instance, the NERDC's sponsored vocabulary of primary science and mathematics in nine Nigerian languages (Hausa, Igbo, Yoruba, Edo, Efik, Fulfulde, Izon, Kanuri and Tiv) is a clear demonstration of the capacity of Nigerian indigenous languages as tools for the development of science and technology.

\section{B. Language as a Tool for National Re-branding Project}

The media, both print and electronics, can redeem Nigeria's image through effective language use. Pornographic language, coarse invective and tirade can be replaced with refined diction, polished syntax and semantic finesse. Columnists, newspapers editors, freelance writers should use language to write on and about the virtue of honesty, dedication to duty, moral rectitude, and selfless service to one's fatherland. They should also write biographies of honourable statesmen and women whose exemplary characters could be regarded as legendary. Such writings have the power of moralizing and hence of re-branding the readers.

Indigenous language, or any language, is regarded as the bedrock of nation building. It is the most important tool with which societies are organized, and it is hardly possible to talk of national development without including the language with which the people formulate their thoughts. According to Olaoye (2007), indigenous languages and languages in general perform the following re-branding role:

- Instrumental Function: Language is used for getting things done. The Federal Ministry of Information uses English and the Nigerian indigenous languages as campaign tools for sensitizing Nigerians on the need for the rebranding project. Languages are used in the training and retraining of civil servants, the academics, the lawmakers, while the politicians are being re-branded through retreats all carried out through the instrumentality of languages. The essence 
being to get these categories of Nigerians imbibe new socio-political, cultural and economic ethos of a new Nigeria. The essence of law-making is also to sanitize the nation so that it will be a peaceful place to live, and to create opportunity for justice, fair play and equalitarianism. Constitutional reform can only be carried out through the use of languages. The essence of this is to re-brand Nigeria and Nigerians. It is to control man's egocentric tendencies, greed, avarice and cleptomania. Lawmaking is a language- sensitive activity or exercise. Responsible and responsive lawmaking is to save people from the clutches of slavery, oppressive rule, corrupt leaders, tyrannical rulers, and to chasten men and women of shady character who have given Nigeria a bad name. Implementing legal, political and economic reforms is tantamount to re-branding the nation, and this task is carried out through languages. Misuse or abuse of language leads to perverse justice, insincerity, rape of democracy, deception and corruption.

- Regulatory Function:- Language is used for controlling people's behaviour, for instance through:

a. Prohibition, as in "don't cheat", "don't urinate here"“don't bribe", “don't take bribe", "don't take what does not belong to you", “don't engage in examination malpractice", "don't join bad gangs", etc.

b. Through threat of reprisal, especially if behaviour is not stopped, as in "I will punish you if you do that again", "you will go to jail if you don't stop stealing", "you will be rusticated if you don't stop cheating during exams", etc.

c. Through disapproval of behaviour, as in "that is bad of you", "No, stop it" that is not done here, etc.

\section{Language, Literature and National Re-branding}

Language, literature and culture are inseparable as tools for national development and as veritable tools for national rebranding. There is no literature without language. Asade (2000) asserts that literature is the matrix of the sociocultural ethos of the people, and the weapon of sustenance. In literary language, satire is an artistic weapon for sanitizing the society. Literature through language, warns people of dangerous and anti-social practices, ridicules people of mean and despicable character, criticizes such evils like corruption, injustice, nepotism, bribery, economic and political sabotage, oppression, colonialism and neocolonialism, dictatorship, racism or colour segregation, literary theft, money laundering, examination malpractice, cultism, armed robbery, militancy, abduction, drug peddling, human trafficking, election rigging, arson, sectarian crisis, looting, extra-judicial killing, etc. Good poetry, songs and music, especially those philosophical ones which extol good virtues and deride ignoble course or action are capable of correcting societal ills.

Language behaviour is rule-governed, and any breach of language and cultural rules attracts sanctions. People's world view is determined by one's language and culture, and this lends credence to Sapir-Whorfian hypothesis of cultural relativism and linguistic determinism. Language is thus a shaper of ideas. We dissect the world through the instrumentality of our indigenous languages. Language adaptation however brings about language growth and development, and this in turn affects man's language and cultural re-orientation, socio-political and economic cosmopolitan out-look and modernism. For instance new words and expressions have entered into the lexicon of our indigenous languages through linguistic globalization. There is knowledge explosion through mass communication and information technology, and all these lead to advancement in science and technology which has a formidable rebranding role to play in nation building. Computer appreciation is now being made easy through the construction of indigenous languages keyboard which has linguistic facilities such as tone markers-diacritics, circumflex, tildes, cedillas, umlaut, special orthographies, etc. The youths become empowered through all these linguistic facilities. An empowered youth is a re-branded youth.

\section{LANGUAGE AND EDUCATIONAL ANDRAGOGY}

Andragogical education is a learner-centered approach which sees the child or learner as quite educable. It thus prepares child- friendly methodology whose goal is communitarian, participatory and altruistic. Learning is to bring about positive change in the learner. This type of education humanizes the learner, and develops his critical and creative thinking. Language is however the tool for achieving andragogical educational goals. Products of this school of philosophy become better and well-cultured politicians, better lawmakers, better leaders, responsible democrats, and well re-branded homo-sapiens. Nigerian languages are veritable instruments for the full empowerment of Nigerians.

The linguistic equivalent of the 1948 Universal Declaration of Human Rights is the 1996 Universal Declaration of Linguistics Rights. These rights are:

- The right to be recognized as a member of a language community.

- The right to the use of one's language, both in private and public life.

- The right to the use of one's own name.

- The right to associate with one's own language community.

- The right to maintain and develop one's own culture.

- The right for one's language and culture to be taught.

- The right of access to cultural services.

- The right to an equitable utilization of one's language and culture in the media.

These rights, Ogunranti (2000) believes, have conferred on all Nigerians, through their MT, the right and opportunity to actively participate in party politics and to express their feelings and emotions through the media. These rights are ingredients of empowerment. Linguistics studies can be regarded as a useful source of empowerment eventuating in 
total re-branding of the people. Empowerment through language education promises the youth an escape from intellectual and economic poverty, and hence from oppression. Applied linguistics for instance is capable of acculturating the youths in the art of speaking, especially public elocution skills, phatic communion skills and illocutionary acts. In political linguistics the youths learn about linguistics and cultural taboos such as diplomatic stealing or computer wizardry called yahooism, another name for internet robbery, and other vices such as rape, avarice, cultism, duping, looting, all of which are vehemently disapproved of in the community. Shunning these vices leads to linguistic and cultural re-branding of the youth. The cultural sanctions that go with the breach of language and cultural etiquette are very severe. Since language can be regarded as the celestial electricity which illuminates the darkest part of the linguistically blind person, the study of language and linguistics is capable of transforming the youth, from their primordial barbarity or pristine primitiveness and reprehensible social misdemeanor, to men and women of moral finesse. From ontological point of view the youths get spiritual empowerment through what Olaoye (2007) calls knowledge of the language of religious worship, i.e. the language of praise worship, intercession and the use of evocative epithets for spiritual "Rite de passage" leading to spiritual cleansing and re-branding.

English Language in Nigeria

Nigeria is a multilingual nation where English Language has acquired the status of a second language to many people, while it is a third language to others. It plays a significant role in education, politics, government administration, the judiciary, economy and legislation. English today can be regarded as the lamp with which the youths can travel through the education tunnel (Ige, 2000). It is even now being referred to as one of the major Nigerian languages (Ogundare 2004). This is because its role as a unifying or integrating force is obvious. It is a compromise language of communication in a multilingual setting since political resistance to the choice of an indigenous language as a national official language has foreclosed choosing any of the three major Nigerian Languages as a Lingua Franca. English according to Adekunle (1974) is the linguistic and symbolic embodiment of political power and authority.

English is the vehicle of globalization, and through it came information and communication technology (ICT) which has a pervasive influence on education delivery. ICT, through television, radio and satellite communication, on-line services, e-mail, computer teleconferencing, has brought the world to the doorstep of the youths and other computer literate people. ICT is therefore a source of youth empowerment, and hence a tool for national re-branding. Through the internet and world news, accessed through English, western democracy has become a regular menu on the nation's political agenda. Political and language education, made possible through globalization, has started to open people's eyes to such issues like the value of peace, justice, freedom, equity, dialogue, compromise, tolerance, reciprocal respect, the essence of following the rule of law, constitutionality and due process, and the need to imbibe the culture of reform. These are some of the ingredients for sustainable democracy, and potent tools for the Nigeria's rebranding project.

\section{CONCLUSION}

For language and literature to contribute effectively to national rebranding project and national development the federal Government needs to be more committed to multilingual and multicultural education. A more serious commitment entails the following:

- A well planned and implemented Mother Tongue Education

-Better and improved production of quality language and literature teachers, provision of modern teaching/instructional materials, improved welfare package for teachers, provision of better infrastructures at both the primary and secondary school levels

- Improved funding of tertiary education

- Well funded research on the development of orthographies and language documentation

- Deliberate promotion of the study of linguistics and language education in Colleges of Education and Universities.

- Better and improved funding of language centres in Nigeria such as NINLAN Aba and Nigerian French Language village, Badagry.

The author believes that a re-branded language education policy, a re-branded language education curriculum, effective language use by the media, can lead to successful political mobilization, cultural re-orientation, moral rearmament, youth empowerment and language education reform that will eventuate in national rebranding, and the actualization of the goals of vision 20-2020.

\section{REFERENCES}

[1] Adekunle, M.A. (1974). The standard Nigerian English in sociolinguistic perspective. Journal of Nigerian English Studies Association (NESA). 6, 1, 24-36.

[2] Asade, B.K. (2000).Language, literature and national development. Language, literature and linguistics in the 21 st century. Kaduna: NCCE Publication.

[3] Awoniyi, T.A. (1978) The mother tongue in education. Yoruba language in education. Ibadan: OUP 15-26.

[4] Aziza, R.O. (1998), Nigerian languages and national development. In O. Arohunmolase (ed.), Nigerian languages for national development. Ibadan: Longman communication.

[5] Bako, M.M. (2004). The role of language in the democratization process. In Shoja et al. (eds.), Language, literature, education and democracy in Nigeria. 2-7. 
[6] Fani-Kayode, F. (2006). Opening remarks at the national workshop on best practices to safeguard endangered Nigerian languages. Abuja: UNESCO.

[7] Fatokun, F. (1992). Introduction to literature and literary criticism. Nigeria Certificate in Education series. Ondo: Ikere Ekiti College of Education.

[8] Graham-Brown, S. (1991). Education in the development worlds. Ibadan: Longman.

[9] Ige,B.S. (2000), Language as a tool for moving education forward in the year 2000 and beyond. Literature and linguistics in the 21 st century. Kaduna; NCCE Publication.

[10] Ishima, J.L.J. (2004). Indigenous languages and technological development: Issues and perspectives. Language, literature, education and democracy in Nigeria.23-27.

[11] Isyaku, K. (2004). Language and literature in education for a better society: The challenges of the 21st century. Language and literature in education for a better society.

[12] Nwadike, E. (2004). The role of Igbo in enhancing national unity, in Oyewole (ed) Nigerian Languages for National Development and Unity. Ibadan: Longman Communication.

[13] Okeshola, R.B. (1995).Gender sensitivity planning in Nigeria. An unpublished paper, Zaria: Ahmadu Bello University.

[14] Ogundare, M.A. (2004). The role of language teaching in national development. Language, literature and education for a better society .60-63.

[15] Ogunranti, J.1. (2000). The role of mother tongue as a medium of instruction in the year 2000 and beyond. Language, literature and linguistics in the $21^{\text {st }}$ century. Kaduna: NCCE Publication.

[16] Olaoye, .A.A (2001). Sociolinguistics of language of Religion in Nigeria. In: Journal of Arabic Studies JARS, University of Ilorin. 15, 17-25.

[17] Olaoye, A.A. (2002). Sociolinguistics of communication skills. Linguistics and literature for language art. Kano: Rainbow Royale Publishers.

[18] Olaoye A.A. (2004). Modern approach to classroom learning: Anandragogical exploration. An unpublished Education Tax Fund workshop paper, July. Argungu,Kebbi State: College of Education.

[19] Olaoye, AA. (2007). Introduction to Sociolinguistics: Text in applied linguistics. Abuja: Israel Ogunieye Publisher.

[20] Olalekan, G.B.A. (2001). Yoruba translation, metalanguage and lexicography. In Oyewole, A. (ed.), Nigerian language, the past, the present and the future. $57-79$.

[21] Opega, R.O.Y, (2004). The teaching of language and literature: Relevance to and reactions of a younger Nigerian generation. Language and literature in education for a better Society

[22] Solanke, J. (2006). What has folklore got to do with it? Endangered languages and the electronic age. Proceedings of the national workshop on best practices to safeguard Nigerian languages. Abuja: UNESCO publication.

Anthony A. Olaoye was born at Okerimi-Oro, in Irepudun Local Government Area of Kwara State, Nigeria on the $4^{\text {th }}$ April, 1949. The author has B.A. (Ed) English/Education, Ahmadu Bello University, Zaria, Nigeria, 1978; M.Ed Curriculum and Instruction, Bayero University, Kano, Nigeria, 1982; M.A. English Language, Bayero University, Kano, Nigeria, 1986; Ph.D, English Language (Sociolinguistics) Ahmadu Bello University, Zaria, Nigeria, 1992.

The author's major field is Applied Linguistics. He has taught English Language and Methodology in a College of Education, and has worked in five different universities in Nigeria, where he taught English Language and Applied Linguistics as a Senior Lecturer. He later rose to the position of an Associate Professor of Applied Linguistics in Kwara State University Malete, Ilorin, Nigeria. He is currently a retired, contract lecturer in the Department of Linguistics and African Languages, University of Abuja, Nigeria. He has 50 publications, with four books, three of which are: Introduction to Sociolinguistics, Abuja, Mafolayomi Press, 2002; Aspects of Applied Linguistics Abuja, Israel Ogunleye Publisher, 2008; Linguistics in Language Education, Abuja, Israel Oguleye publisher, 2009. His previous and current research interest is in Ethnography of Communication and Language Documentation.

The author's title is Dr. Olaoye, Associate Professor of Applied Linguistics. He is a member of ten Professional Associations some of which are listed below:

- West African Linguistic Congress (WALC)

- Linguistic Association of Nigeria (LAN)

- Association of Nigerian Languages Teachers (ANLAT)

- Nigerian Institute of Management (NIM)

- Curriculum Organization of Nigeria (CON)

- Nigerian English Studies Association (NESA)

- Reading Association of Nigeria (RAN)

- Standing Conference of Teachers of English Language (SCONTEL)

$\mathrm{He}$ is an awardee of the British Council/Cambridge Summer School Scholarship for Post-Doctoral Language Education Short Course, Homerton College, Cambridge, 1993. He is also a commissioned Language Education Consultant to the National Commission for Colleges of Education (NCCE) and the National Institute for Cultural Orientation (NICO), in Nigeria. 